\title{
Changing Salaries, Changing Minds: Examining the Merits of Merit Pay
}

\author{
Joshua H. Barnett \\ Arizona State University \\ jhbarnett@asu.edu \\ Roger Openshaw \\ Massey University, New Zealand \\ r.openshaw@massey.ac.nz
}

\begin{abstract}
Policymakers across the globe are actively seeking reforms that lead to improved student performance. One reform gaining momentum is the usage of merit pay for educators who are able to increase performance on standardized measures. However, educators' voices are often missing from the discussion, as policies are put onto them rather than determined with them. The present paper examines the historical landscape in one country, infuses the growing international literature on merit pay into the conversation, and makes recommendations for those considering the inclusion or creation of such pay for performance models and how educators can help shape the policies.
\end{abstract}

\section{Introduction}

Teacher retention and recruitment concerns are arising in Parliaments and legislative bodies across the globe. One growing policy response is to change the financial incentive structure for teachers by creating merit, or pay-for-performance systems. For example, researchers are examining the effects of policy changes to teacher salaries in Great Britain (Atkinson et al, 2004); the United States of America (e.g. Podgursky \& Springer, 2006), India (Muralidharan \& Sundararaman, 2008), Kenya (Glewwe, Ilias, \& Kremer, 2004), and Australia (Gordon \& Colebatch, 2008; Ferrari, 2008). Following this international trend, educators in all nations should consider how they will respond when the debate inevitably appears on their legislature's agenda because evidence indicates that policymakers are being persuaded to alter teacher salaries with or without teacher input.

Before delving into the potential merit pay response from teachers and their respective organizations, a general understanding of the purpose behind merit pay is worth noting. The theory of action for merit pay programs purports that they positively impact the teaching corps in two ways - through motivational impacts and compositional impacts. First, proponents contend that the possibility of earning financial rewards based on increased student achievement or other selected measures will motivate current teachers to focus their efforts on the measured subjects through innovation and additional effort. Second, those more willing to work within a competitive environment where their skills will be rewarded rather than marginalized (due to the flat structure of most current teacher salary schedules) will lead to an increased applicant pool for positions. Further, a systematic change can occur where those most successful at impacting student learning are retained, while those less

Journal of Contemporary Issues in Education, 2011, 6(1), pp.24-34

ISSN 1718-4770 @ 2011 University of Alberta

http://ejournals.library.ualberta.ca/index.php/JCIE 
impactful, acknowledged by receiving smaller bonuses, are ushered out of the profession. Notwithstanding these theoretical benefits of merit pay, the following essay discusses how educators, who are faced with decisions about how to react within the increasing era of accountability, may consider engaging.

We believe educators have several different response options. They could reject the whole notion out of-hand. Another strategy would be to simply bow to what increasingly looks like an inevitable change. These two choices, however, prevent educators from having a voice in shaping policies, which will undoubtedly impact them and their classrooms. In this paper, we advocate a position which may allow educators to have an active and positive impact on the debate. This position requires educators to be much more savvy about the merits or otherwise of the various salary changes.

Hence, the focus of the present paper is three-fold. First, we survey the historical reception accorded merit pay in New Zealand. New Zealand was selected because salary policy changes, including merit pay, are re-emerging on the political radar; however, actual changes remain under consideration. Second, we examine the broad, international literature regarding merit pay with reference particularly to the experience in U.S.A., where merit pay has also resurfaced within an educational accountability influx. Third, we offer recommendations for educators in New Zealand and across the globe as the debate becomes less academic and more practical with policymakers eagerly seeking ways to improve student performance.

\section{New Zealand and Merit Pay: The Historical Record}

In New Zealand the development of strong nation-wide teachers' unions and their support for the continuation of a national salary scale coupled with a grading system in which teachers and schools were regularly appraised by school inspectors, effectively discouraged the introduction of any system of merit or performancerelated pay. Over the years, however, there have been numerous attempts to pinpoint the qualities that underpin good teaching practice. In the early 1970s, a report by a curriculum review group set up under the auspices of the secondary teachers union, the New Zealand Post-Primary Teachers' Association (NZPPTA), attempted to specify in detail the performances required of teachers, at a time when the traditional academic curriculum, teaching methods and examination system were being questioned (New Zealand Post-Primary teachers' Association, 1974; Introduction, xiii). In seeking to more exactly specify classroom aims so that teachers could measure their own performance against a stated ideal, NZPPTA outlined five basic premises they felt should underlie teachers' professional roles:

1. making one's own decisions about student needs in the classroom

2. accepting responsibility for diagnosis including designing and implementing learning programmes and evaluating the results

3. accepting responsibility for one's professional decisions and actions

4. demonstrating intellectual and educational integrity

5. understanding the limitations to what could be achieved by teachers (pp.1-5).

By the mid-1980s, however, there were increasing calls for the external monitoring of teacher performance. In November 1986 the Education and Science Select Committee announced its intention to conduct an inquiry into the quality of teaching. The committee claimed to have uncovered considerable disquiet about current methods of accountability in teaching, arguing that many parents and communities had lost confidence in how teachers and principals were being held to 
account for the quality of teaching. The Report also claimed that there was widespread recognition that some teachers were unsatisfactory; 'they damage the children they teach, and parents have expressed their strong concern' (Education and Science Select Committee, 1986, pp.7-8).

The Select Committee Report concluded that teacher professionalism (like professionalism in medicine and law), required accountability, but that job security was over-protective of teachers and worked against quality. It recommended that education boards should be much more closely involved in appointment, promotion and renewal of teacher contracts. Teachers would be eligible for promotion only if they had undertaken relevant courses of training. The Report argued that school staff along with the wider school community should participate in short-listing candidates for principal positions. There was support for regular reviews of staff that would be tied to performance, whilst promotion to all positions of responsibility was to be on limited tenure (Education and Science Select Committee, 1987, pp.30-34). Merit/performance pay, however, was not specifically mentioned.

During the 1980s, various groups in New Zealand were also highlighting the failure of New Zealand schools and teachers to achieve fairness and equity of outcomes. In November 1987 of a two-volume report from the New Zealand Council for Educational Research (NZCER), submitted to the Royal Commission on Social Policy, a high-profile committee charged by the government with conducting a wideranging examination of New Zealand society leading to recommendations concerning future social policy including education. The first paragraph of the initial volume of the NZCER report set the tone for what was a highly critical analysis of New Zealand's educational achievements over the first one hundred years of its existence centring on the unequal outcomes of those groups identified as being disadvantaged:

This report examines the fairness of the New Zealand education system in relation to seven groups identified as likely to be disadvantaged. They are: those from low socio-economic status homes; girls and women; Maori, Pacific Island groups; the disabled; ethnic migrant groups; and rural dwellers. Allowing for overlap between these categories, this accounts in fact for at least three fifths of the population included broadly within the education system (italics mine). (New Zealand Council for Educational Research, 1987, p. 1)

In paving the way for comprehensive educational reform in New Zealand, The Picot Report and Tomorrow's Schools drew upon much of this broadly based criticism of teachers and schools, exemplified by the Scott Report and by the NZCER submission to the Royal Commission on Social Policy. Subsequent legislation in 1989 saw the abolition of the former Department of Education and its replacement by a new Ministry of Education, the creation of Boards of Trustees elected by local parents to run schools, and the setting up of an Educational Review Office (ERO) to carry out institutional inspections (Butterworth \& Butterworth, 1998). Each school was required to develop a charter setting out its educational aims in some detail and most schools soon introduced a system of individual teacher appraisal.

Community disenchantment with the performance of schools and teachers, coupled with this new more receptive environment created by the educational reforms encouraged an environment in which debate over merit/performance related pay could more readily take place. The whole issue, however, continued to be regarded with considerable suspicion within educational circles, especially by the teachers' unions. In late 1994, for instance, a special working group consisting of representatives from 
the NZEI, the State Services Commission, the Ministry of Education, the Education Review Office, the New Zealand School Trustees Association and several independent members met to consider a number of issues including a unified pay scale, teacher performance and accountability, and principal's contracts (Report of the Working Group on Primary Teachers' Pay, Performance and Accountability, 1994). The State Services Commission proposed that the working group fully examine the notion of rewarding teachers on the basis of performance and merit (Kirk, 1994, p.4). The NZEI, however, remained strongly opposed to performance related pay for two main reasons: first, that systems that rewarded all excellent performers had proven to be extremely expensive and for this reason been mostly abandoned and second, that performance pay had a de-motivating effect on teachers; hence it undermined the very factors that contributed to good schools and teaching (Beresford, 1994).

In addition, a report by independent consultants Deloitte Touche Tohmatsu, commissioned by the working group, noted that merit pay had broad appeal in the United States because it appeared 'consistent with popular assumptions about free enterprise' (Deloitte Touche Tohmatsu, 1994, p.19). Citing US studies by Murname and Cohen (1986), and by McNamara (1992), the report claimed that most merit pay plans had been abandoned within a few years of being adopted. The reasons given included: the narrowing of the curriculum to readily assessed elements, the incentives for teachers to spend more time with those students whose performance they were more likely to improve, 'teaching to the test', the negative impact on effective school teamwork, the reduction of staff morale and the discouragement of a collegial working environment (p.20). Hence, if teacher appraisal was too closely tied to a performance pay related system, then it would become a mere mechanistic exercise for teachers (p.29).

Since the 1990s, the merit/performance pay debate in relation to teachers has been largely muted. A widely cited recent New Zealand text on performance appraisal of teachers expressly excluded discussion of performance pay and merit pay programs as being outside the scope of current appraisal systems for teachers (Cardno \& PiggotIrvine, 1997). A clear distinction was drawn between appraisal and assessment. Appraisal was seen as focusing on judging the value of an individual teacher or manager on the basis of a negotiated job prescription that contained specific and personally agreed performance expectations. Whilst it was conceded that this could be drawn upon in making salary-related decisions, it was seen as a fundamentally different activity to assessment, which made direct comparisons between teachers, as the former school inspectorate had once done (Cardno \& Piggot-Irvine, 1997, p.16).

It could be argued, however, that the introduction from 2001, of the Labour Government's major flagship teacher professional development programme, Te Kōtahitanga, has encouraged a growing tendency in New Zealand to focus not just on school effectiveness as the major determinant of student achievement, but on teacher culpability for the failure of New Zealand's indigenous Maori students to achieve at similar levels to the European majority. This clearly has flow-on implications for the merit/performance pay debate, particularly as Te Kōtahitanga has been widely touted as the answer to the longstanding issue of Maori student underachievement.

The programme has, however, recently been strongly critiqued in a review commissioned by NZPPA. In questioning the programme's claims for outstanding success, the review highlighted serious methodological and conceptual flaws. It was observed that Te Kōtahitanga sits clearly within a growing body of international school effective/school improvement literature that has been seen by some critics as exemplifying a model of 'blame and redemption' (Openshaw, 2007). The programme 
was seen to draw on the ideology of cultural essentialism to identify the teacher's supposedly negative attitude towards Maori culture as the major factor in Maori student underachievement (Openshaw, 2007). In addition, the review found evidence that a significant number of teachers felt pressured to opt into the programme and discouraged from opting out, whilst a disturbing number of teachers reported instances of bullying by senior management within schools (Openshaw, 2007).

The continued political support for Te Kōtahitanga, however, reflects the growing tendency for New Zealand politicians and others to focus increasingly on teacher performance. In turn, this is likely to increase the attractiveness to both politicians and bureaucrats, of extremely crude, reactive and mechanistic versions of performancerelated pay, especially for those teachers who can be shown to demonstrate success with Māori pupils. A paper on current issues in Māori schooling recently released by the Maxim Institute (2006), provoked in part by the alleged successes of $\mathrm{Te}$ Kōtahitanga, argues that some form of performance related pay needs to be introduced as a useful way of attracting and retaining teachers in immersion or bilingual settings, or in mainstream schools where there are a significant number of Māori pupils (p.14).

Moreover, the current tendency in New Zealand for finger-pointing and apportioning blame, as revealed in the Scott Report and evidenced in Te Kōtahitanga, may well encourage a version of performance pay based solely on the degree to which individual teachers have been successful or unsuccessful in demonstrating particular qualities as measured by someone deemed to know what should count as evidence of teacher success or failure. Thus if, for argument's sake, Māori achievement does not rise dramatically, as the designers of Te Kōtahitanga predict it should, then it could then be argued that recalcitrant teachers have simply failed to effectively implement the recommended strategies, with further justification for the application of either carrot or stick. Policymakers in New Zealand are not alone in trying to consider policies to improve performance; recruit, retain, and reward effective teachers; or identify ways to reform their educational agencies. As these conversations continue to take shape, a broader review of what is known about merit pay is needed.

\section{Teachers Respond to Merit Pay}

\section{Merit Pay in Practice}

Over the last decade, merit pay systems have re-emerged as part of the educational landscape; however, rigorous evaluations of these programs are difficult to locate (Figlio \& Kenny, 2006; Murnane \& Cohen, 1986). One existing systematic review and three studies that explicitly address the effects of merit pay on teachers were located. The review was conducted by Chamberlin, Wragg, Haynes, and Wragg (2002) through the Teachers' Incentive Pay Project at the University of Exeter in the United Kingdom and examined research into the effects of pay for performance for public sector jobs, including education. The review examined research on merit pay systems as related to motivation, recruitment, and retention of high quality teachers, as well as the neglect of unrewarded tasks, disagreement about meritorious actions, lack of cooperation, increased costs, and demotivation for unrewarded teachers. According to the authors, such little evaluative evidence for merit pay systems was found that no systematic conclusions could be drawn.

Further highlighting the limited amount of evidence on teachers, only three studies were located that explicitly examine the views of educators. In 1988, Horace Johns evaluated the Tennessee (U.S.A.) Master Teacher Plan. The Master Teacher Plan was designed to improve teacher motivation and reduce teacher alienation and 
thus increase the recruitment and retention of high quality teachers. The survey asked a series of questions in an effort to understand three issues. First, how do the teachers of Tennessee perceive the plan? Second, do teachers feel more or less motivated by the plan? Third, do teachers feel more or less alienated by the plan?

According to the results of the evaluation, the program was not effective. Of Tennessee's teachers who responded, 91 percent reported that the plan was not a significant factor in making them want to keep teaching, 92 percent reported that the plan did not increase morale for teachers, 91 percent reported that the plan did not increase their enthusiasm for teaching, and 89 percent stated that other methods would be better for recruiting and retaining high quality teachers.

In 1994, Horan and Lambert conducted an evaluation of the Utah (U.S.A.) Career Ladder Program. The Career Ladder Program was intended to attract and retain "good" teachers and improve the quality of schools in Utah. Based on the evaluation, the Career Ladder Program positively impacted teacher morale. Ninety percent of the teachers and principals believed that the extended days and staff development improved their working environment and enhanced the teaching profession. Teachers and principals provided mixed reviews of the performance bonus and ladder levels, indicating that these were important components but less important than other aspects of the program.

In 2007, Barnett, Ritter, Winters, and Greene examined the impact of a merit pay program operating in Arkansas (U.S.A.) on the perceptions and attitudes of teachers. The evaluation asked teachers specifically about the oft-cited advantages and disadvantages of merit pay. According to the results of the teacher survey, which compared program teachers to comparable peers in non-program schools, three teacher related findings emerged. First, with regard to the advantages of merit pay programs, the researchers found that the teachers in the merit pay program did not report being more innovative or working harder, but the program teachers did report being more satisfied with their salaries. Second, with regard to the disadvantages of merit pay programs, the researchers found that the teachers in the merit pay program did not report higher levels of negative competition, did not report their school climate worsened, and did not report focusing on only high-performing students. Finally, the evaluation concludes by indicating that with nearly a two-to-one margin, the program teachers reported that the academic performance of their students improved over the previous year.

The findings from these evaluations and systematic review highlight the limited but growing evaluations regarding merit pay and teacher behavior. The next section examines the extant literature surrounding the effects of merit pay on student achievement.

\section{Effectiveness of Merit Pay on Students}

The literature describing the effectiveness of merit pay programs to improve student performance is also limited but growing. According to a systematic review conducted by Podgursky and Springer (2006), the majority of evaluations they located concluded that student achievement improved as a result of merit pay. Within their review, they discuss merit pay programs in the United States (Clotfelter \& Ladd, 1996; Eberts et al, 2002; Figlio \& Kenney, 2006; Ladd, 1999), Great Britain (Atkinson et al, 2004), Kenya (Glewwe et al, 2004), and Israel (Lavy, 2002; 2004). According to these studies, merit pay programs improved math and reading test scores, course completion rates, attendance, grade point averages, and reduced dropout rates. These findings are supported by the recent evaluations conducted by 
Barnett et al. (2007) and Ritter et al. (2008), which found that a merit pay program in Arkansas improved math achievement scores by approximately seven percentile points.

Given the landscape of international information regarding merit pay, as well as the current trend to design and implement programs, the next section of this paper addresses the historical and current education trends in New Zealand with an eye towards merit pay programs.

\section{Where Do We Go From Here?}

So, the stage is set. New Zealand's education system is facing the similar strains and demands felt across the globe - increase student performance, while not discouraging or discounting the hard work of teachers. It seems clear that some merit pay systems are markedly better than other ways of improving teacher performance, such as those that depend on coercion or on singling out teaches for blame if student performance does not improve. While the extant literature is not uniform in supporting merit pay, some elements of merit pay programs do intuitively and from the evidenced-based literature seem to warrant genuine consideration when discussing the how and why of this policy. As is often the case with policies, we encourage efforts to tease out the good from the bad elements, rather than rejecting the notion altogether.

First, without question, the successful merit pay plans are simple. That is, the program should be able to be described in straightforward and clear statements. Second, the successful merit pay plans are consistent across years. Once a program is agreed upon within the school - then changes to the payouts or the formula will be viewed negatively. For example, according to the year two evaluation (Ritter et al., 2008) of a merit pay program in Arkansas, U.S.A., teachers communicated that the merit pay program was not communicated to them clearly, and the payout program changed between years, both of which created confusion and negative attitudes towards the program.

Third, the literature is consistent in that the successful merit pay plans are noncompetitive for teachers and staff members. The early failures of many merit pay plans are those in which teachers must compete against one another in order to achieve greater bonuses. Rather, the most successful plans encourage cooperation and support by providing teachers with bonuses against a standard, where all teachers who achieve receive rewards. In this manner, all teachers can achieve the highest marks, which encourages teachers to continue working together and sharing ideas. This third issue also raises a separate, but equally valuable, lesson - successful merit pay plans reach beyond the teachers in the classroom. Merit pay plans can (and in our opinion) should be comprehensive school bonus programs. That is to say, the principal, education coaches, aides, counselors and support staff all contribute in varying degrees of responsibility to the education of students. The successful school environment is created best when all of these individuals can work cohesively as one unit aiming to improve achievement.

Fourth, the successful merit pay plans will attach significant bonuses for accomplishing goals. Policymakers cannot expect teachers to change their behaviour for the proverbial peanut bonus. The primary failure of low-paying plans is that teachers simply do not feel as though the perceived additional work is worth the potential pay. Recall the theory of merit pay is based, in part, on a motivational 
impact. Bonuses must be made commensurate with existing pay scales to ensure that they motivate change.

Finally, the successful merit pay plan provides rewards based on improvements in teacher characteristics and student performance. Merit pay plans designed to provide incentives to educators whose students pass a threshold (i.e. exemplary, high-achieving, passing), do little to encourage growth or improvement for all students. Rather, such programs do much to incentivize teachers to desire working with the already highest performing students. Similarly, rewards for teachers to earn additional credentials are point-in-time efforts, and such policies do little to encourage or maintain consistent improvement. Conversely, plans designed to reward teachers for improvements in their own teaching processes (via parent, peer, or principal evaluations) and their students' gains encourage teachers to work with all students and to continue refining their skills.

\section{Conclusion}

As educators and policymakers across the globe consider various reward structures, we contend that in order to have educators' voices represented, they must fundamentally reject the "blame and redemption" philosophy often found in education policies, which clearly do not successfully encourage a collaborative environment. Additionally, under many current educational policies (in New Zealand and other countries), teachers are simply punished if they do not improve performance, which can bring negativity and fear into the classroom. As such, educators would do well to consider the growing international evidence of rewarding teachers for success, rather than focusing on punishments when students do not improve. One policy area where teachers can be rewarded, which might include bonuses for working in high-needs or hard-to-staff areas (i.e. special education, math, science), is the idea of merit pay. The vehicle to deliver merit, however, is an important tenant of the conversation. As is often the case, the devil is in the details. What is known is that blaming teachers for low performing students or flat achievement levels does little to invite new professionals into the field, retain those already working in field, or reward those succeeding against all odds. 


\section{References}

Atkinson, A., Burgess, S., Croxon, B., Gregg, P., Propper, C., Slater, H., \& Wilson, D. (2004). Evaluating the Impact of Performance-related Pay for Teachers in England. University of Bristol: Centre for Market and Public Organization.

Barnett, J. H., Ritter, G. W., Winters, M. A., \& Greene, J. P. (2007). How does Merit Pay Affect Students and Teachers? An evaluation of the Achievement Challenge Pilot Project. Working Paper, Department of Education Reform, University of Arkansas. Retrieved January 25, 2007, from www.uark.edu/der/papers

Beresford, J. (1994). Letter to A.R. Kirk, Branch Manager, Government Operations Branch, State Services Commission, Wellington dated 29 July. Appendices to Report of the Working Group on Primary Teachers' Pay, Performance and Accountability. Wellington: December.

Bishop, R, Berryman, M., Tiakiwai, S. and Richardson, C. (2003). Te Kōtahitanga: The Experiences of Year 9 and 10 Màori Students in Mainstream Classrooms. Report to the Ministry of Education. Rangahau Matauranga Māori. Māori Education Research. NZ Ministry of Education. Wellington.

Bishop, R., Berryman, M., Cavanagh, T., \& Teddy, L. (2007). Te Kōtahitanga Phase 3 Whanaungatanga: Establishing a Culturally Responsive Pedagogy of Relations in Mainstream Secondary School Classrooms. Final Report. Ministry of Education Research Division, Wellington (March).

Bishop, R., Berryman, M., Powell, A., \& Teddy, L. (2007). Te Kōtahitanga Phase 2 Towards a Whole School Approach. Ministry of Education, Wellington (March).

Butterworth, G. and Butterworth, S. Reforming Education. The New Zealand Experience 1984-1996. Dunmore Press for the New Zealand Ministry of Education: Palmerston North.

Cardno, C., and Piggot-Irvine, E. (1997). Effective Performance Appraisal. Integrating Accountability and Development in Staff Appraisal. Auckland: Addison Wesley Longman.

Chamberlin, R., Wragg, T., Haynes, G., \& Wragg, C. (2002). Performance-related pay and the teaching profession: A review of the literature. Research Papers in Education, 17(1), 31-49.

Clotfelter, C. \& Ladd, H. (1996). Recognizing and Rewarding Success in Public Schools. In H. Ladd (Ed), Holding Schools Accountable: Performance-related Reform in Education. Washington D.C.: The Brookings Institution.

Coddington, D. (2007). Cited in Openshaw, R. (2007). Review of Te Kōtahitanga Phase 3. Wellington: New Zealand Post-primary Teachers' Association.

Deloitte Touche Tohmatsu (1994). Performance and Accountability of Primary Teachers. Appendices to Report of the Working Group on Primary Teachers' Pay, Performance and Accountability. Wellington: December.

Eberts, R., Hollenbeck, K., \& Stone, J. (2002). Teacher performance incentives and student outcomes. Journal of Human Resources, 37(4), 913-927.

Education and Science Select Committee (1986). Report of the Inquiry into the Quality of Teaching. . Second Session, Forty-first Parliament (Noel Scott, Chairman). Wellington: Government Printer.

Elam, S. M. (1989). The second Gallup/Phi Delta Kappa poll of teachers' attitudes toward the public schools. Phi Delta Kappa, 66(2), 97-

Ferrari, J. (2008). Gillard all for merit pay in classroom. The Australian. 
Figlio, D. N., \& Kenny, L. (2006). Individual teacher incentives and student performance. National Bureau of Economic Research Working Paper 12627. Retrieved January 2, 2007, from http://papers.nber.org/papers/w12627

Glewwe, P., Ilias, N., \& Kremer, M. (2004). Teacher Incentives. Mimeograph. Cambridge, MA: Harvard University.

Goldhaber, D. (2002). The Mystery of Good Teaching. Education Next, 1, 50-55.

Gordon, J., \& Colebatch, T. (2008). Devaluing our teachers. The Age.

Horan, C. B., \& Lambert, V. (1994). Evaluation of Utah career ladder programs. Beryl Buck Institute for Education. Utah State Office of Education and Utah State Legislature. (ERIC Document Reproduction Service No. SP035206).

Jensen, N. C., Riffel, B. E., Ritter, G. W., Holley, M. J., \& Barnett, J. H. (2008). Understanding the effects of performance pay on teacher behaviour: Lessons from the Achievement Challenge Pilot Project. Paper presented at the 2008 annual meeting of the American Education Finance Association. Denver, CO.

Johns, H. E. (1988). Faculty perceptions of a teacher career ladder program. Contemporary Education, 59(4), 198-203.

Kirk, A.R. (1994). Letter to J. Beresford, Assistant Secretary, Industrial Professional Team, New Zealand Educational Institute entitled 'Primary school teachers and management contracts negotiations', 28 July. Appendices to Report of the Working Group on Primary Teachers' Pay, Performance and Accountability). Wellington: December.

Ladd, H. (1999). The Dallas school accountability and incentive program: an evaluation of its impacts on student outcomes. Economics of Education Review, $18(1), 1-16$.

Lavy, V. (2002). Evaluating the effect of teachers' group performance incentives on pupil achievement. Journal of Political Economy, 110(6), 1286-1317.

Lavy, V. (2004). Performance Pay and Teachers' Effort, Productivity and Grading Ethics. National Bureau for Economic Research Working Paper 10622. Cambridge: NBER

Lazear, E. (2003). Teacher Incentives. Swedish Economic Policy Review, 10, 197213.

Lazear, E. (2002). Performance pay and productivity. American Economic Review, 90, 1346-1361.

Muralidharan, K., \& Sundararaman, V. (2008). Teacher incentives in developing countries: Experimental evidence from India. National Center on Performance Incentives Working Paper. Retrieved February 29, 2008 from http://www.performanceincentives.org/news__events/detail.asp?pageaction=View SinglePublic \&LinkID=236\&ModuleID=38

Murnane, R. J., \& Cohen, D. K., (1986). Merit pay and the evaluation problem: why most merit pay plans fail and a few survive. Harvard Educational Review, 56, pp. $1-17$.

New Zealand Council for Educational Research (1987). How Fair is New Zealand education? Part 1. NZCER submission to the Royal Commission on Social Policy. Wellington.

New Zealand Post-Primary Teachers' Association (1974). Teachers in Change. Report of the Curriculum Review Group on the Education and Training of Secondary teachers.

Openshaw, R. (2007). Review of Te Kōtahitanga - Phase 3. Wellington: New Zealand Post-primary Teachers' Association. 
Podgursky, M. J., \& Springer, M. G. (2006). Teacher performance pay: A review. Available from the National Center on Performance Incentives. Retrieved from, http://www.performanceincentives.org

Report of the Working Group on Primary Teachers' Pay, Performance and Accountability (1994). Wellington: December. 